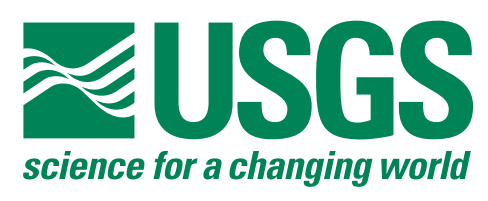

\title{
Seasonal Flux and Assemblage Composition of Planktic Foraminifera From the Northern Gulf of Mexico, 2008-14
}

By Caitlin E. Reynolds and Julie N. Richey

Open-File Report 2016-1115 


\title{
U.S. Department of the Interior SALLY JEWELL, Secretary
}

\section{U.S. Geological Survey Suzette M. Kimball, Director}

\author{
U.S. Geological Survey, Reston, Virginia: 2016
}

For more information on the USGS - the Federal source for science about the Earth, its natural and living resources, natural hazards, and the environment—visit http://www.usgs.gov or call 1-888-ASK-USGS.

For an overview of USGS information products, including maps, imagery, and publications, visit http://store.usgs.gov/.

Any use of trade, firm, or product names is for descriptive purposes only and does not imply endorsement by the U.S. Government.

Although this information product, for the most part, is in the public domain, it also may contain copyrighted materials as noted in the text. Permission to reproduce copyrighted items must be secured from the copyright owner.

Suggested citation:

Reynolds, C.E., and Richey, J.N., 2016, Seasonal flux and assemblage composition of planktic foraminifera from the northern Gulf of Mexico, 2008-14: U.S. Geological Survey Open-File Report 2016-1115, 14 p., http://dx.doi.org/10.3133/ofr20161115.

ISSN 2331-1258 (online) 


\section{Contents}

Abstract
Introduction..1.
Regional Setting
Materials and Methods.
Results From 2013
Results From 2014
Discussion
Conclusions.
Acknowledgments

\section{Figures}

1. Map showing location of the sediment-trap mooring in the northern Gulf of Mexico at approximately $27.5^{\circ} \mathrm{N}$. lat, $90.3^{\circ} \mathrm{W}$. long ....

2. Graphs showing temperature/depth profiles of World Ocean Atlas 2009 climatology data, averaged monthly and conductivity-temperature-depth casts for the sediment trap during 2008-14

3. Graphs showing salinity/depth profiles of World 0cean Atlas 2009 climatology data, averaged monthly and conductivity-temperature-depth casts for the sediment trap during 2008-14.

4. Graphs showing average daily flux of 7- to 14-day-long sampling intervals of all planktic foraminifers and the 10 most abundant taxa during 2008-14.

5. Graphs showing weekly relative abundance, in percent, of the 10 most common taxa of planktic foraminifers during 2008-14.

\section{Table}

[Available for download in Excel format from http://dx.doi.org/10.3133/ofr20161115]

1. Planktic foraminiferal flux and relative contribution in percent to the total assemblage for the 14 most common taxa, northern Gulf of Mexico 


\section{Conversion Factors}

International System of Units to Inch/Pound

\begin{tabular}{lcl}
\hline \multicolumn{1}{c}{ Multiply } & By & \multicolumn{1}{c}{ To obtain } \\
\hline & Length & \\
\hline meter $(\mathrm{m})$ & 3.281 & foot $(\mathrm{ft})$ \\
kilometer $(\mathrm{km})$ & 0.6214 & mile (mi) \\
\hline \multicolumn{2}{c}{ Area } & \\
\hline square meter $\left(\mathrm{m}^{2}\right)$ & 10.76 & square foot $\left(\mathrm{ft}^{2}\right)$ \\
\hline
\end{tabular}

Temperature in degrees Celsius $\left({ }^{\circ} \mathrm{C}\right)$ may be converted to degrees Fahrenheit $\left({ }^{\circ} \mathrm{F}\right)$ as

$$
{ }^{\circ} \mathrm{F}=\left(1.8 \times{ }^{\circ} \mathrm{C}\right)+32 .
$$




\title{
Seasonal Flux and Assemblage Composition of Planktic Foraminifera From the Northern Gulf of Mexico, 2008-14
}

\author{
By Caitlin E. Reynolds and Julie N. Richey
}

\begin{abstract}
The U.S. Geological Survey anchored a sediment trap in the northern Gulf of Mexico in January 2008 to collect seasonal time-series data on the flux and assemblage composition of live planktic foraminifers. This report provides an update of the previous time-series data to include continuous results from January 2013 through May 2014. Ten taxa constituted $~ 95$ percent of both the 2013 and 2014 assemblages: Globigerinoides ruber (pink and white varieties), Globigerinoides sacculifer, Globigerina calida, Globigerinella aequilateralis, Globorotalia menardii group [The Gt. menardii group includes Gt. menardii, Gt. tumida, and Gt. ungulata], Orbulina universa, Globorotalia truncatulinoides, Pulleniatina spp., and Neogloboquadrina dutertrei. In 2013, the mean daily flux was 177 tests per square meter per day $\left(\mathrm{m}^{-2}\right.$ day $\left.^{-1}\right)$, with maximum fluxes of $>1,200$ tests $^{-2}$ day $^{-1}$ during the middle of February and minimum fluxes of $<13$ tests $\mathrm{m}^{-2}$ day $^{-1}$ during the beginning of November. In 2014, the mean daily flux was 189 tests $\mathrm{m}^{-2}$ day $^{-1}$, with maximum fluxes of $>900$ tests $\mathrm{m}^{-2}$ day $^{-1}$ at the end of January and minimum fluxes of $<30$ tests $\mathrm{m}^{-2}$ day $^{-1}$ at the beginning of January. Globorotalia truncatulinoides showed a clear preference for the winter, consistent with data from 2008 to 2012. Globigerinoides ruber (white) flux data for 2012 (average 23 tests $\mathrm{m}^{-2}$ day $^{-1}$ ) were consistent with data from 2011 (average 30 tests $\mathrm{m}^{-2}$ day $^{-1}$ ) and 2010 (average 29 tests $\mathrm{m}^{-2}$ day $^{-1}$ ) and showed a steady threefold increase since 2009 (average 11 tests $\mathrm{m}^{-2}$ day $^{-1}$ ) and a tenfold increase from the 2008 flux $\left(3\right.$ tests $\mathrm{m}^{-2}$ day $^{-1}$ ). The flux data from 2013 (average 15 tests $\mathrm{m}^{-2}$ day $^{-1}$ ) and 2014 (average 8 tests $\mathrm{m}^{-2}$ day $^{-1}$ ) showed decline from the previous 3 years.
\end{abstract}

\section{Introduction}

A sediment trap was moored in the northern Gulf of Mexico in January 2008 as part of a U.S. Geological Survey Mendenhall Postdoctoral Fellowship project. The sediment trap, equipped with an automated sampling system, collected material in the water column from January 2008 to May 2014. In March 2015, the trap could not be recovered, and attempts to retrieve it were unsuccessful. A new sediment trap having the same specifications as the original trap was subsequently deployed and resumed collecting data in November 2015. Information on the trap, the trap mooring, planktic foraminifers as climate proxies, and the results from the first year (2008) are detailed in Tedesco and others (2009). In this report, we update results from the sediment-trap series to include material collected between January and December 2013 and between January and May 2014. This report presents the data without interpretation. For discussion and interpretation of flux data from 2008 to 2010, see Poore and others (2013). 


\section{Regional Setting}

The Gulf of Mexico is a semi-enclosed basin surrounded by the Gulf Coast of the United States, Mexico, and Cuba (fig. 1). Sea-surface temperature at the trap site ranges from a winter low of approximately 21 degrees Celsius $\left({ }^{\circ} \mathrm{C}\right)$ to a summer high of $30{ }^{\circ} \mathrm{C}$ (World Ocean Atlas 2009 data cited in Locarnini and others, 2010). Sea-surface salinity ranges from about 35 practical salinity units (psu) in the winter to $32 \mathrm{psu}$ in the summer (World Ocean Atlas 2009 data cited in Antonov and others, 2010).

The Gulf of Mexico is connected to the Caribbean Sea and tropical North Atlantic Ocean by the Loop Current. The Loop Current is a surface current that enters the Gulf of Mexico from the Caribbean Sea between Cuba and the Yucatan Peninsula and typically loops to the east and south before exiting through the Straits of Florida.

The Gulf of Mexico, Caribbean Sea, and western tropical North Atlantic Ocean compose the Atlantic Warm Pool, the Atlantic portion of the Western Hemisphere Warm Pool (Wang and Enfield, 2001). The Atlantic Warm Pool is defined by the region of water warmer than $28.5^{\circ} \mathrm{C}$ and constitutes a large part of the tropical heat engine, supplying moisture to the atmosphere and latent heat to North America from early spring to early fall (Wang and Enfield, 2001; Wang and others, 2006). World Ocean Atlas 2009 climatology data indicate the trap site is part of the Atlantic Warm Pool during the summer months of July, August, and September (Locarnini and others, 2010).

\section{Materials and Methods}

A McLane PARFLUX Mark 78 automated sediment trap was deployed in early January 2008 at approximately $27.5^{\circ} \mathrm{N}$. lat, $90.3^{\circ} \mathrm{W}$. long, in about 1,150 meters $(\mathrm{m})$ of water. The trap was positioned in the water column at a depth of $700 \mathrm{~m}$ on the mooring cable to guarantee the collection of deeper dwelling species of planktic foraminifers (for example, Globorotalia spp.). The trap was equipped with 21 collection cups mounted on a rotating plate that was programmed to rotate every 7 to 14 days (representing a 1- or 2-week collection period). From January 2008 to late May 2009, sample cups contained a buffered formalin solution made with seawater filtered at 0.44 micrometers $(\mu \mathrm{m})$ and having an ambient salinity of approximently 33 psu. Since September 2009, sample cups have contained a density-gradient solution having a salinity of approximately 44 psu. Formalin ( 3.7 percent) and sodium borate were added to the density-gradient solution to poison and preserve the samples in all years of the study. The trap was recovered and redeployed every 3 months during 2008, and approximately every 6 to 9 months thereafter. A gap in sampling occurred between late May and late September 2009 and from the beginning of February to late March 2012 due to scheduling problems. Ten samples, one each from the weeks of March 17, April 7, May 5, October 22, November 19, and December 10, 2009; January 7, February 14, and February 24, 2010; and February 2013, were not recovered due to loss of the sampling cups during deployment and (or) recovery. The trap was lost at sea and became unrecoverable in March 2015, which represents the end of the data series presented in this report. A new sediment trap was deployed and resumed collecting samples in November 2015. During visits to the trap site, conductivity-temperature-depth (CTD) measurements (figs. 2 and 3) were collected using a Sea-Bird Electronics SBE9plus instrument.

Sediment-trap samples were processed and analyzed at the Department of Earth and Ocean Sciences, University of South Carolina, Columbia, S.C., under a cooperative agreement with the U.S. Geological Survey. Samples were wet split into four aliquots using a precision rotary splitter, stored in buffered de-ionized water, and refrigerated. A quarter split was wet sieved over a $150-\mu \mathrm{m}$ sieve and subsequently wet picked for all foraminifers. In samples containing fewer than 300 foraminifers in the first quarter split, an additional quarter split was processed and picked. The counts were then summed. All planktic foraminifers were identified to species. The species counts are reported as flux in tests per square meter per day $\left(\mathrm{m}^{-2} \mathrm{day}^{-1}\right)$. Flux was calculated by multiplying the individual species counts by number of splits, then dividing by the total duration of the sampling period, which was typically 7 or 14 days. Relative abundance (percentage of each species relative to the total number of individuals within each cup) is 
reported weekly and for each season. Seasonal flux is the total flux for each individual species. Seasons are defined as winter (January, February, and March), spring (April, May, and June), summer (July, August, and September), and fall (October, November, and December). Relative seasonal abundances were calculated by dividing the total seasonal flux of each species by the total seasonal flux for all planktic foraminifers.

\section{Results From 2013}

From the sediment-trap material, 10 taxa of planktic foraminifers constituted $\sim 95$ percent of both the 2013 and 2014 assemblage: Globigerinoides ruber (d'Orbigny) (pink and white varieties), Gs. sacculifer (Brady), Globigerina calida Parker, Globigerinella aequilateralis (Brady), Globorotalia menardii group [The Gt. menardii group includes Gt. menardii (Parker, Jones, and Brady), Gt. tumida (Brady), and Gt. ungulata Bermudez], Orbulina universa d'Orbigny, Gt. truncatulinoides (d'Orbigny), Pulleniatina spp., and Neogloboquadrina dutertrei (d'Orbigny) (table 1; figs. 4 and 5).

The mean daily flux of planktic foraminifers recovered from the trap in 2013 was 177 tests $\mathrm{m}^{-2}$ day $^{-1}$ (table 1; fig. 4). The winter flux composed $\sim 67$ percent of the annual flux and ranged from 108 to 1,244 tests $^{-2}$ day $^{-1}$, with a mean flux of 409 tests $\mathrm{m}^{-2} \mathrm{day}^{-1}$. The spring flux contributed $\sim 13$ percent of the annual flux and ranged from 50 to 231 tests $\mathrm{m}^{-2}$ day $^{-1}$, with a mean flux of 119 tests $\mathrm{m}^{-2}$ day $^{-1}$. The summer flux contributed $\sim 8$ percent of the annual flux and ranged from 29 to 85 tests $\mathrm{m}^{-2} \mathrm{day}^{-1}$, with a mean flux of 59 tests $\mathrm{m}^{-2}$ day $^{-1}$. The fall flux contributed $\sim 12$ percent of the annual flux and ranged from 12 to 189 tests $\mathrm{m}^{-2}$ day $^{-1}$, with a mean flux of 75 tests $\mathrm{m}^{-2}$ day $^{-1}$.

Globorotalia truncatulinoides was the most abundant species in the winter season, composing $\sim 33$ percent of the assemblage during January-March 2013 (fig. 5). The spinose species Globigerinoides ruber (pink) (10 percent), Globigerinoides ruber (white) (10 percent), Globigerinoides sacculifer (16 percent), and Globigerina calida (28 percent), accounted for the bulk of the spring percentage ( $\sim 4$ percent combined). The summer season was dominated by the Globigerinoides genus (Gs. ruber (pink), Gs. ruber (white), and Gs. sacculifer), which made up $\sim 66$ percent of the total assemblage. Gs. ruber (pink) (10 percent), Gl. aequilateralis ( 9 percent), N. dutertrei (21 percent), and Pulleniatina spp. (31 percent) accounted for $\sim 71$ percent of the fall assemblage.

\section{Results From 2014}

The mean daily flux of planktic foraminifers recovered from the trap in 2014 was 189 tests $\mathrm{m}^{-2}$ day $^{-1}$ (table 1; fig. 4). The winter flux contributed $\sim 86$ percent of the annual flux (January-May) and ranged from 29 to 970 tests $\mathrm{m}^{-2}$ day $^{-1}$, with a mean flux of 222 tests $\mathrm{m}^{-2}$ day ${ }^{-1}$. Globorotalia truncatulinoides was again the most abundant species in the winter season, and composed $~ 54$ percent of the assemblage during January-March 2014

(fig. 5). The spring (April and May only) flux contributed $\sim 14$ percent of the annual flux (January-May) and ranged from 47 to 182 tests $\mathrm{m}^{-2}$ day $^{-1}$, with a mean flux of 99 tests $\mathrm{m}^{-2}$ day $^{-1}$.

\section{Discussion}

The sediment record has shown that Gs. ruber (white) is a major component ( $20-30$ percent) of the late Holocene planktic foraminifer assemblages (Kennett and others, 1985; LoDico and others, 2006; Poore and others, 2011). However, in this study, Gs. ruber (white) has been anomalously low (1.5 percent (2008), 5 percent (2009), $\sim 14$ percent (2010, 2011, and 2012), 8 percent (2013), and $\sim 4$ percent for the first five months of 2014). The addition of 2013-2014 data to the 2008-12 flux (Reynolds and others, 2013) and percentage data provide for a better understanding of the inter-annual and intra-annual variability. A longer time series is needed to distinguish the natural range of all foraminiferal species. 


\section{Conclusions}

Sediment-trap data collected from January 2008 to May 2014 show that 10 taxa of planktic foraminifers composed $\sim 93$ percent of the total flux for the period. Globorotalia truncatulinoides flux data indicate that the species is present mostly during the winter months of January, February, and March.

\section{Acknowledgments}

We thank Eric Tappa (University of South Carolina), Kaustubh Thirumalai (University of Texas), Joe Malbrough (Louisiana Universities Marine Consortium), and the crew of the Louisiana Universities Marine Consortium research vessel Pelican for assistance in deploying and redeploying the sediment-trap mooring.

\section{References Cited}

Antonov, J.I., Seidov, D., Boyer, T.P., Locarnini, R.A., Mishonov, A.V., Garcia, H.E., Baranova, O.K., Zweng, M.M., and Johnson, D.R., 2010, World Ocean Atlas 2009, Volume 2: Salinity, in Levitus, S., ed., NOAA atlas NESDIS 69: Washington, D.C., U.S. Government Printing Office, 184 p.

Kennett, J.P., Elmstrom, K., and Penrose, N.L., 1985, The last deglaciation in Orca Basin, Gulf of Mexico: Highresolution planktonic foraminifera changes: Palaeogeography, Paleoclimatology, Paleoecology, v. 50, p. 189-216.

Locarnini, R.A., Mishonov, A.V., Antonov, J.I., Boyer, T.P., Garcia, H.E., Baranova, O.K., Zweng, M.M., and Johnson, D.R., 2010, World Ocean Atlas 2009, Volume 1: Temperature, in Levitus, S., ed., NOAA atlas NESDIS 68: Washington, D.C., U.S. Government Printing Office, 184 p.

LoDico, J.M., Flower, B.P., and Quinn, T.M., 2006, Subcentennial-scale climatic and hydrologic variability in the Gulf of Mexico during the early Holocene: Paleoceanography, v. 21, no. 3, http://dx.doi.org/10.1029/2005PA001243.

Poore, R.Z.; Tedesco, K.A., and Spear, J.W., 2013. Seasonal flux and assemblage composition of planktic foraminifers from a sediment-trap study in the northern Gulf of Mexico, in Brock, J.C., Barras, J.A., and Williams, S.J., eds., Understanding and predicting change in the coastal ecosystems of the northern Gulf of Mexico: Journal of Coastal Research, Special Issue 63, p. 6-19.

Poore, R.Z., Verardo, S., Caplan, J., Pavich, K., and Quinn, T., 2011, Planktic foraminiferal relative abundance and trends in Gulf of Mexico Holocene sediments-Records of climate variability, in Buster, N.A., and Holmes, C.W., eds., Gulf of Mexico origin, waters, and biota; v. 3, Geology: Texas A\&M University Press, p. 367-379.

Reynolds, C.E., Richey, J.N., and Poore, R.Z., 2013, Seasonal flux and assemblage composition of planktic foraminifera from the northern Gulf of Mexico, 2008-2012: U.S. Geological Survey Open-File Report 2013-1243, 13 p., http://pubs.usgs.gov/of/2013/1243/.

Tedesco, K.A., Spear, J.W., Tappa, Eric, and Poore, R.Z., 2009, Seasonal flux and assemblage composition of planktic foraminifera from the northern Gulf of Mexico: U.S. Geological Survey Open-File Report 2009-1293, 19 p.

Wang, Chunzai, and Enfield, D.B., 2001, The tropical Western Hemisphere Warm Pool: Geophysical Research Letters, v. 28 , no. 8 , p. $1635-1638$.

Wang, Chunzai, Enfield, D.B., Lee, Sang-ki, and Landsea, C.W., 2006, Influences of the Atlantic Warm Pool on Western Hemisphere summer rainfall and Atlantic hurricanes: Journal of Climate, v. 19, p. 3011-3028. 


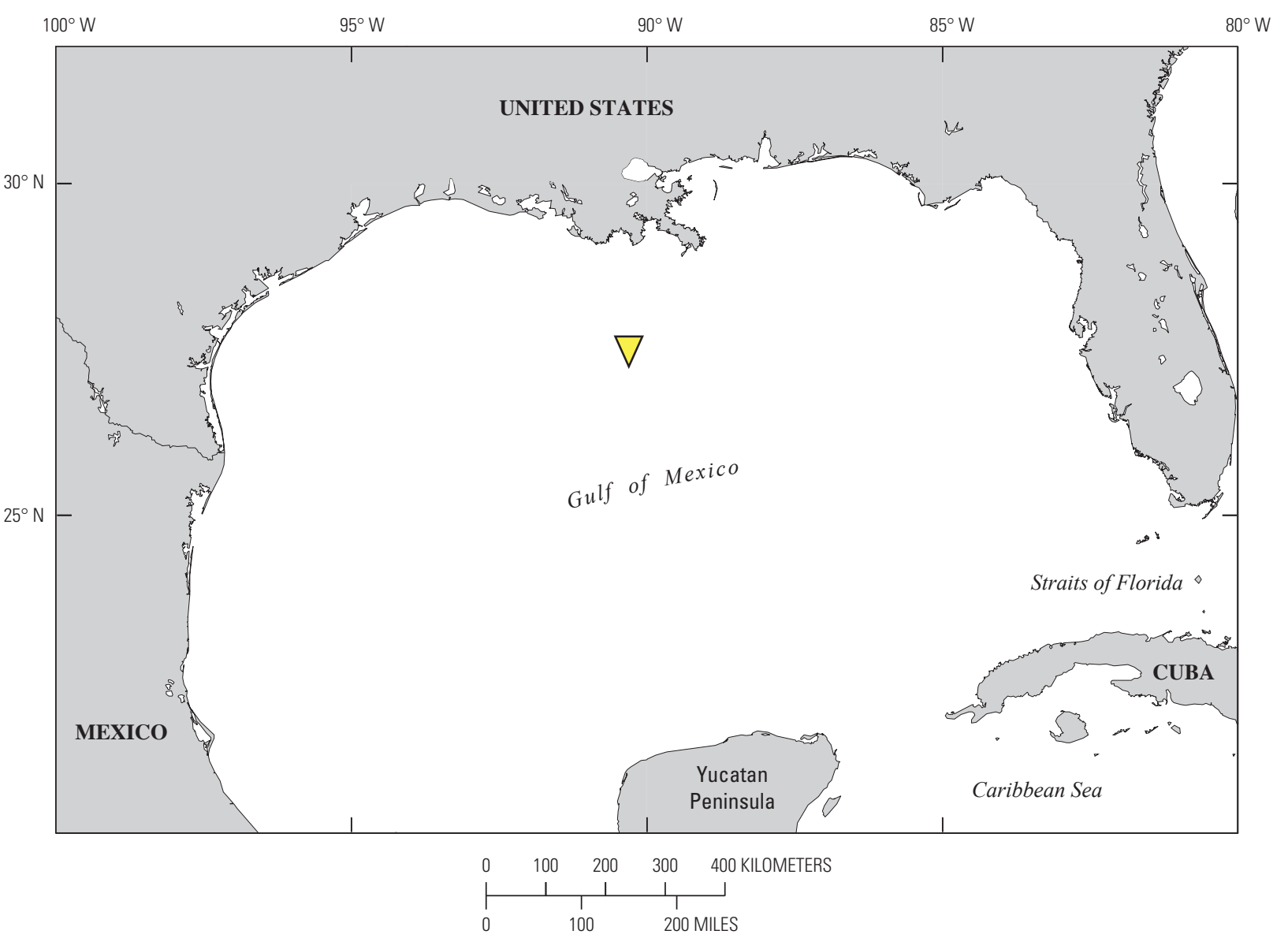

Figure 1. Location of the sediment-trap mooring (inverted yellow triangle) in the northern Gulf of Mexico at approximately $27.5^{\circ} \mathrm{N}$. lat, $90.3^{\circ} \mathrm{W}$. long. 


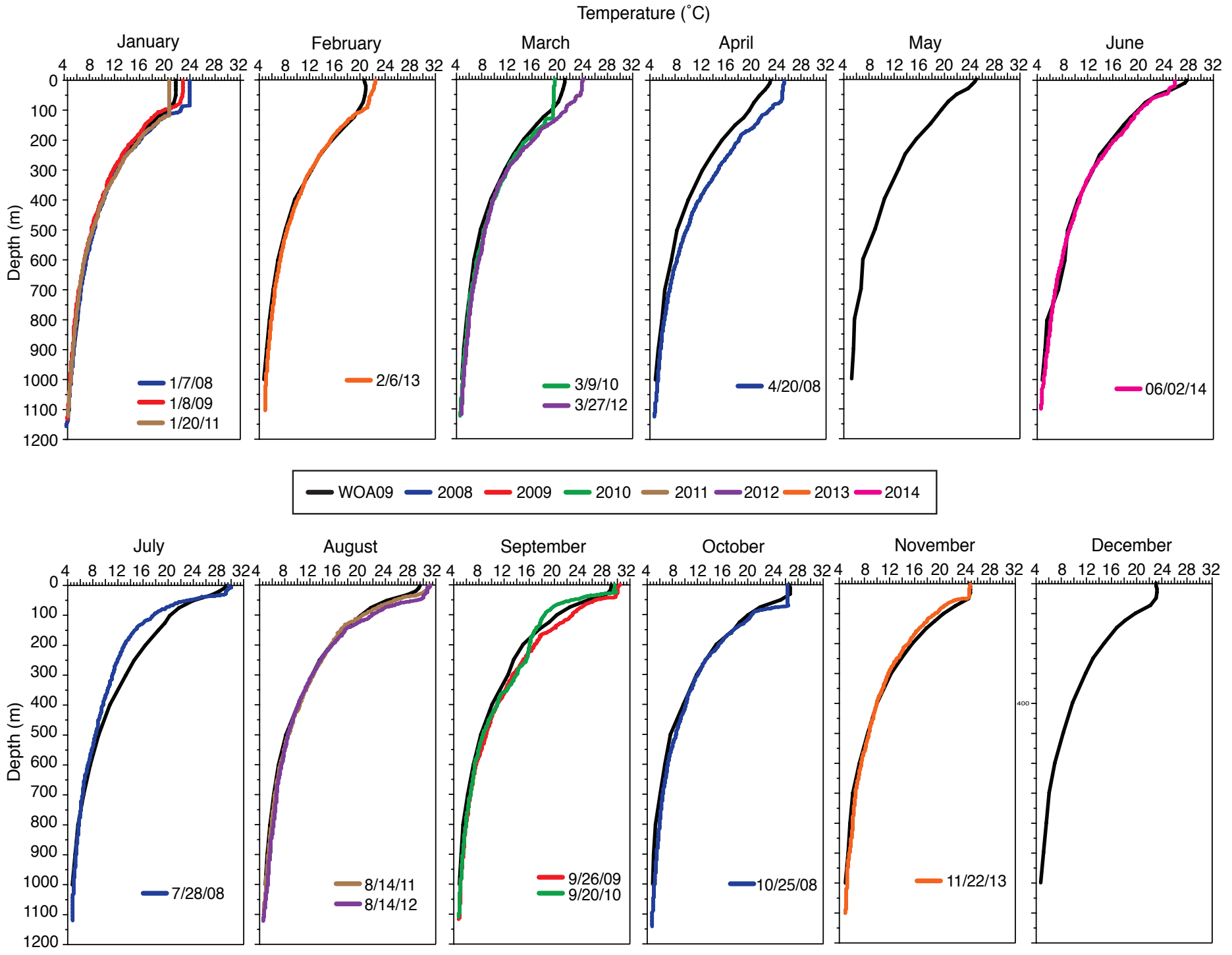

Figure 2. Temperature/depth profiles of World Ocean Atlas 2009 (W0A09) climatology data, averaged monthly (black lines) and conductivity-temperature-depth (CTD) casts for the sediment trap during 2008 (blue lines), 2009 (red lines), 2010 (green lines), 2011 (brown lines), 2012 (purple lines), 2013 (orange lines), and 2014 (pink lines). W0A09 data are cited in Locarnini and others (2010). Abbreviations: $\mathrm{m}$, meter; ${ }^{\circ} \mathrm{C}$, degree Celsius. 


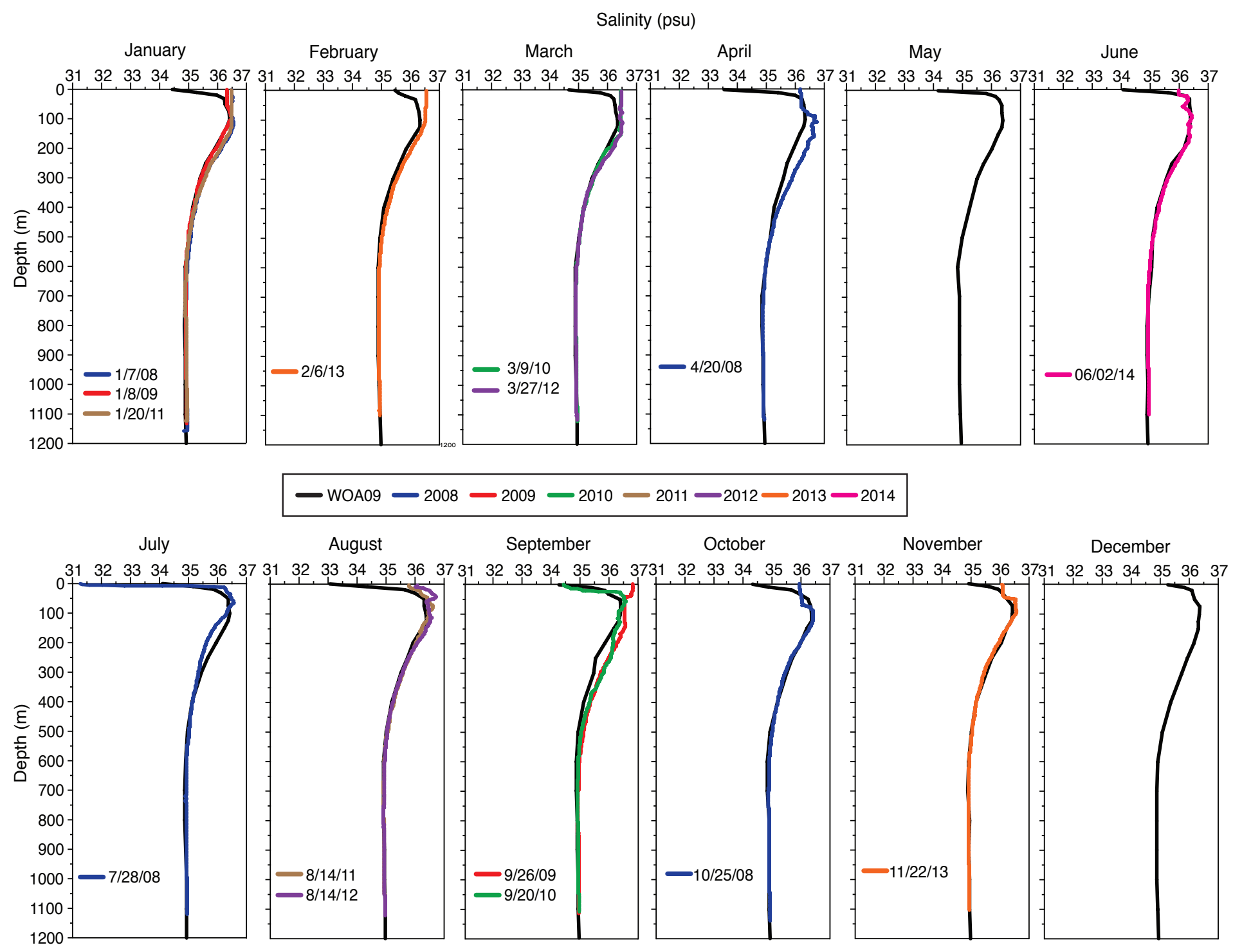

Figure 3. Salinity/depth profiles of World Ocean Atlas 2009 (WOA09) climatology data, averaged monthly (black lines) and conductivity-temperature-depth (CTD) casts for the sediment trap during 2008 (blue lines), 2009 (red lines), 2010 (green lines), 2011 (brown lines), 2012 (purple lines), 2013 (orange lines), and 2014 (pink lines). WOA09 data are cited in Antonov and others (2010). Abbreviations: $\mathrm{m}$, meter; psu, practical salinity unit. 


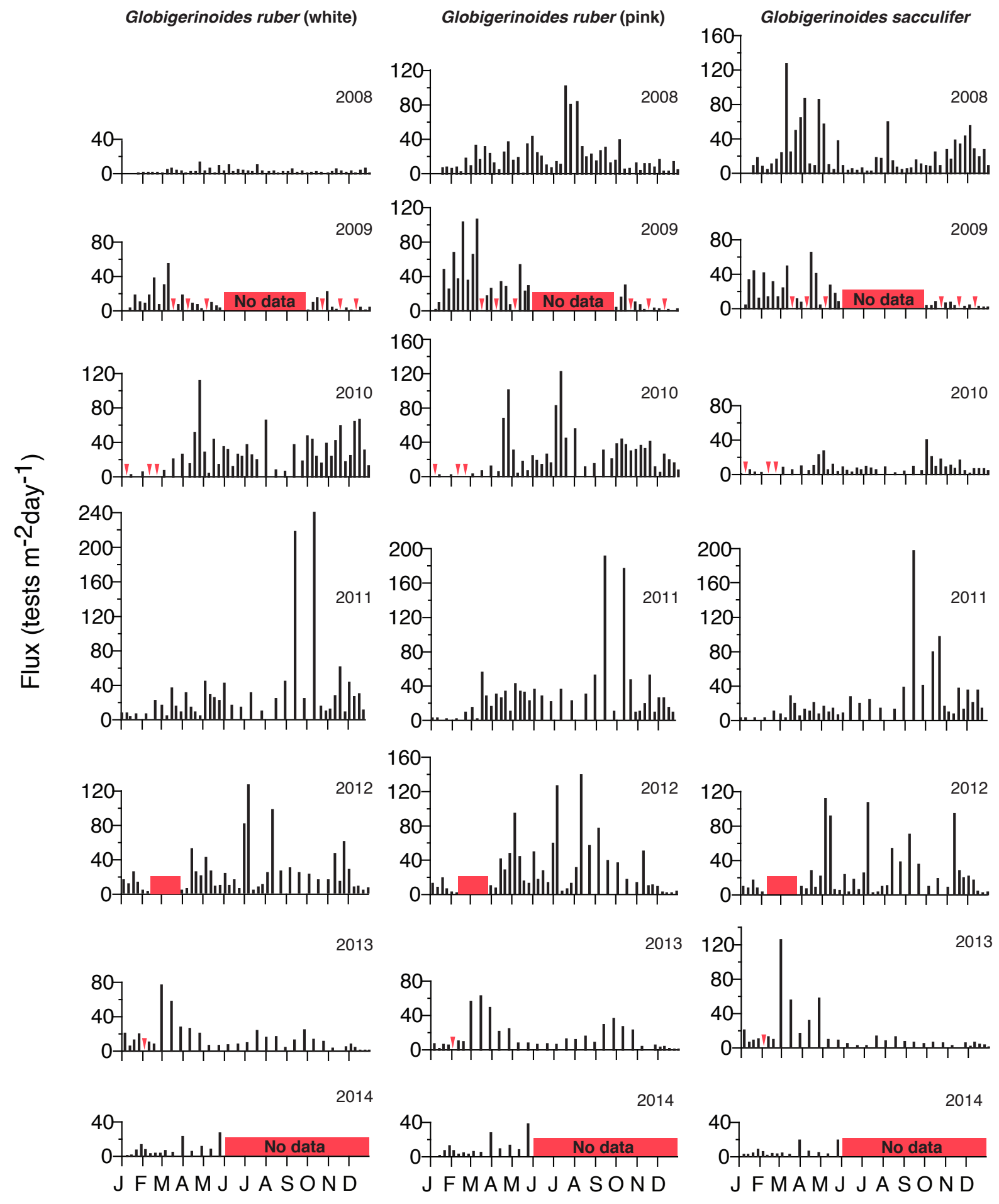

Figure 4. Average daily flux of 7- to 14-day-long sampling intervals of all planktic foraminifers and the 10 most abundant taxa during 2008-14. Note the scale change on the $y$-axis. Tick marks on the $x$-axis denote the first day of each month. Red bars indicate a gap in sampling from late May to late September 2009, from early February to late March 2012, and from June to December 2014. Red inverted triangles indicate the loss of ten sampling cups in 2009, 2010, and 2013. Abbreviation: $\mathrm{m}^{-2}$ day $^{-1}$, per square meter per day. 


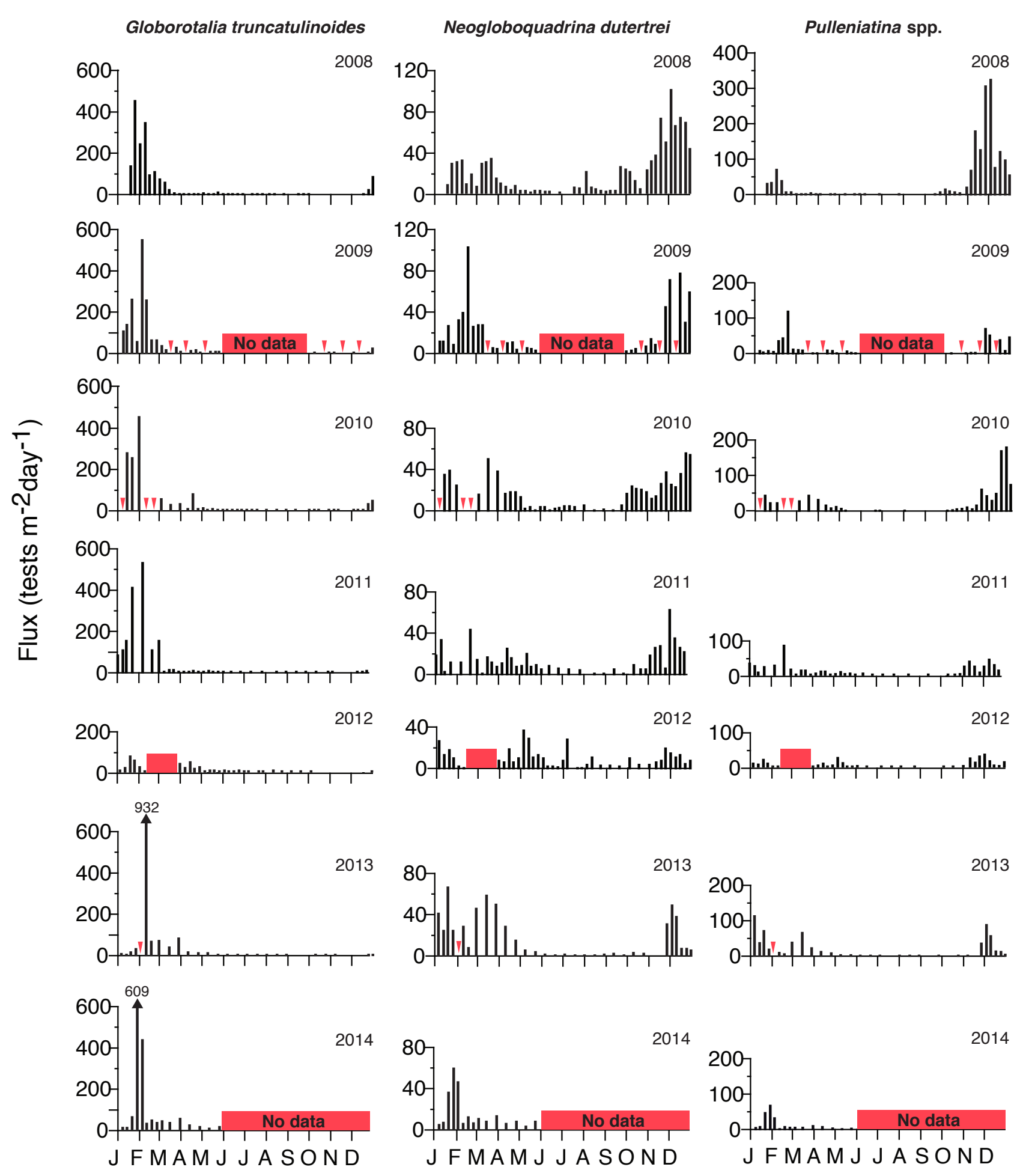

Figure 4. Average daily flux of 7- to 14-day-long sampling intervals of all planktic foraminifers and the 10 most abundant taxa during 2008-14. Note the scale change on the $y$-axis. Tick marks on the $x$-axis denote the first day of each month. Red bars indicate a gap in sampling from late May to late September 2009, from early February to late March 2012, and from June to December 2014. Red inverted triangles indicate the loss of ten sampling cups in 2009, 2010, and 2013. Abbreviation: $\mathrm{m}^{-2}$ day $^{-1}$, per square meter per day.-Continued 

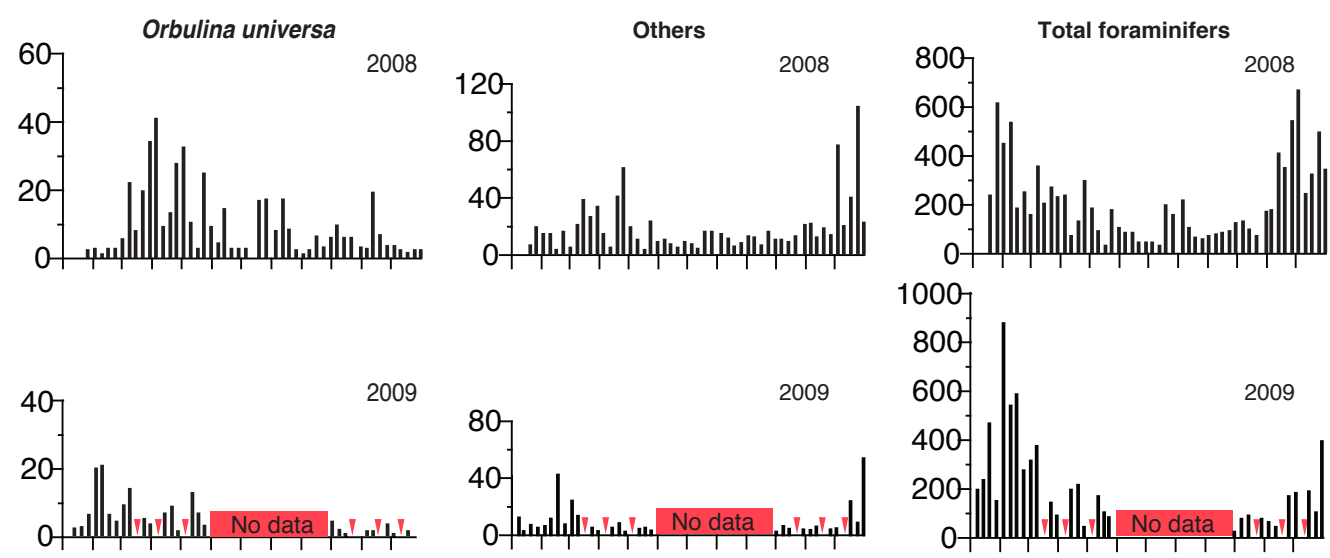

009
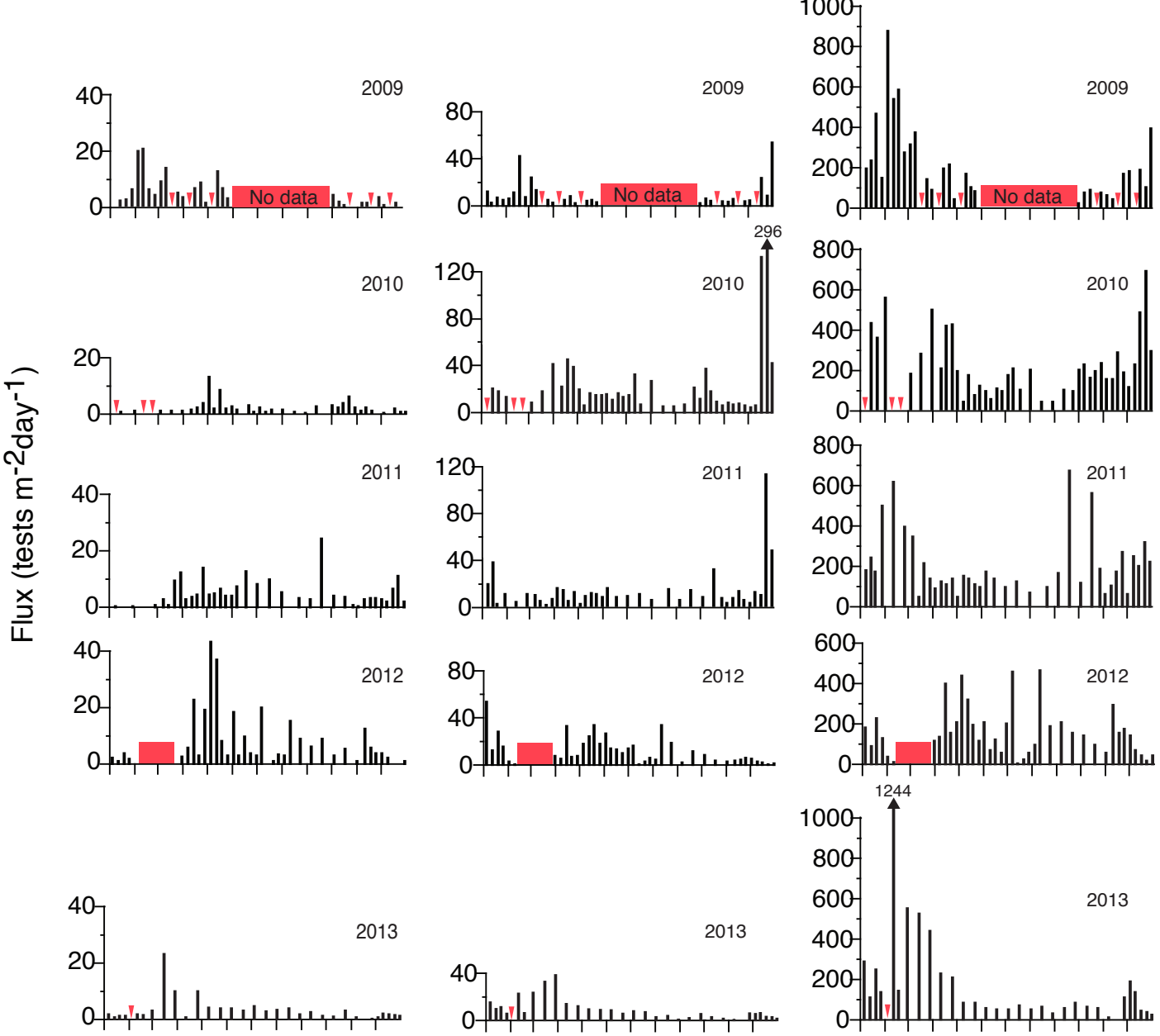

2014
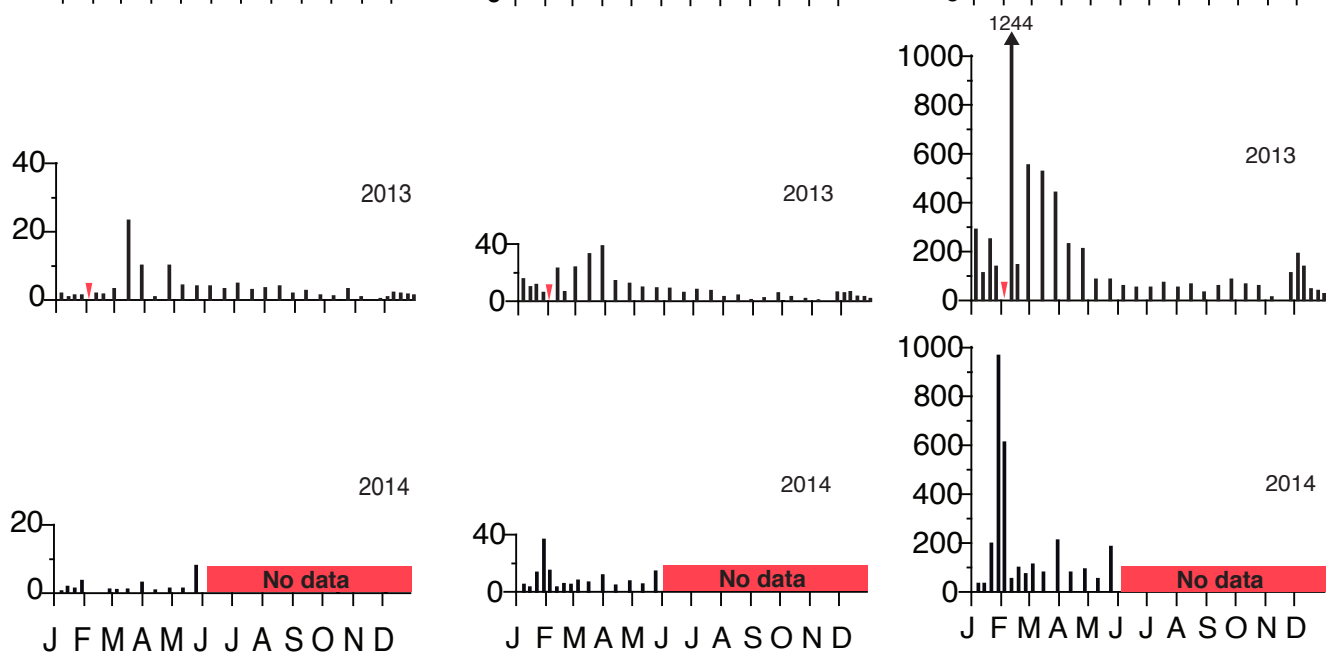

Figure 4. Average daily flux of 7- to 14-day-long sampling intervals of all planktic foraminifers and the 10 most abundant taxa during 2008-14. Note the scale change on the $y$-axis. Tick marks on the $x$-axis denote the first day of each month. Red bars indicate a gap in sampling from late May to late September 2009, from early February to late March 2012, and from June to December 2014. Red inverted triangles indicate the loss of ten sampling cups in 2009, 2010, and 2013. Abbreviation: $\mathrm{m}^{-2}$ day $^{-1}$, per square meter per day.-Continued 
Globorotalia menardii group

Globigerina calida

Globigerinella aequilateralis

2008
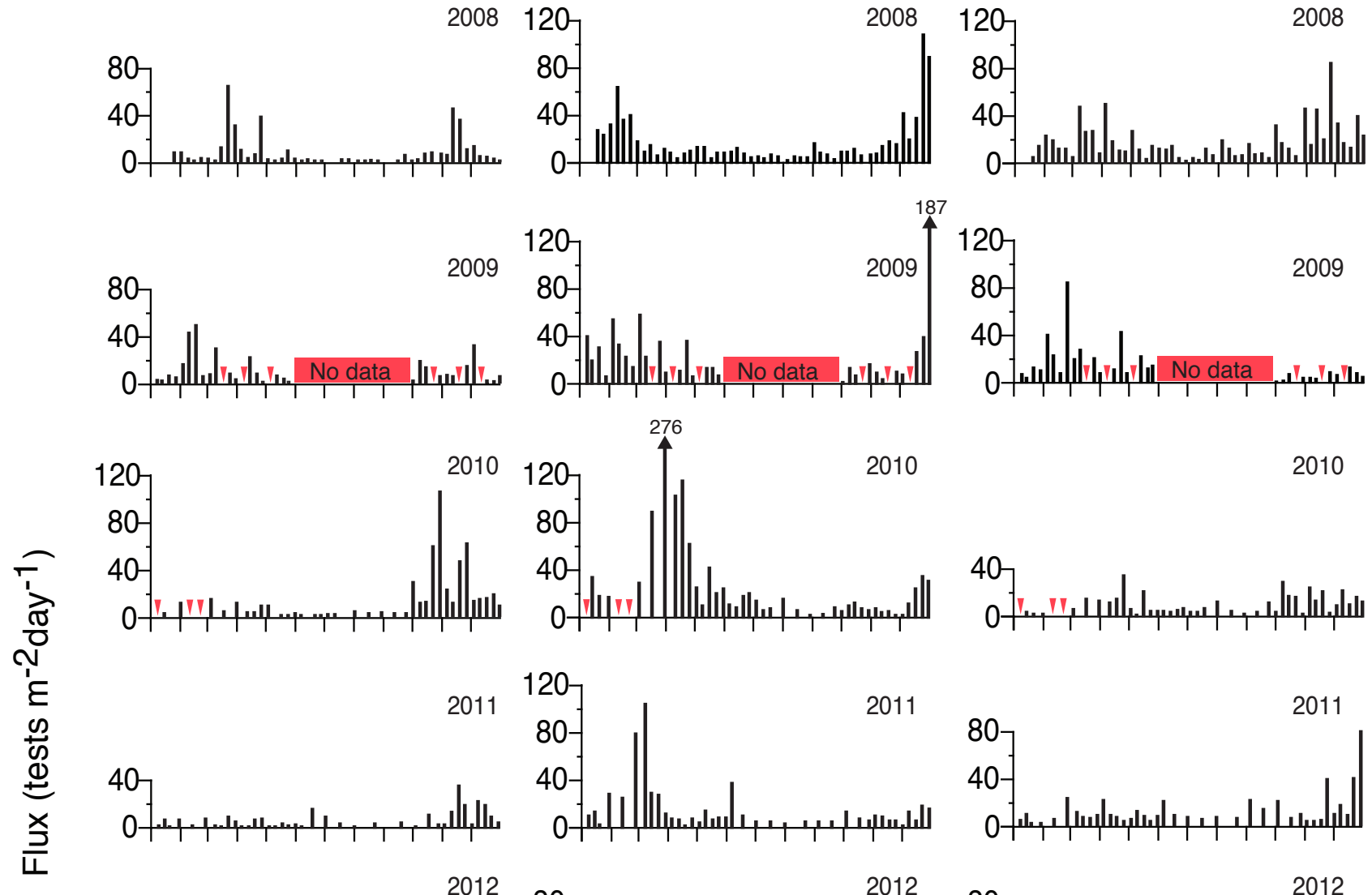

010

2010
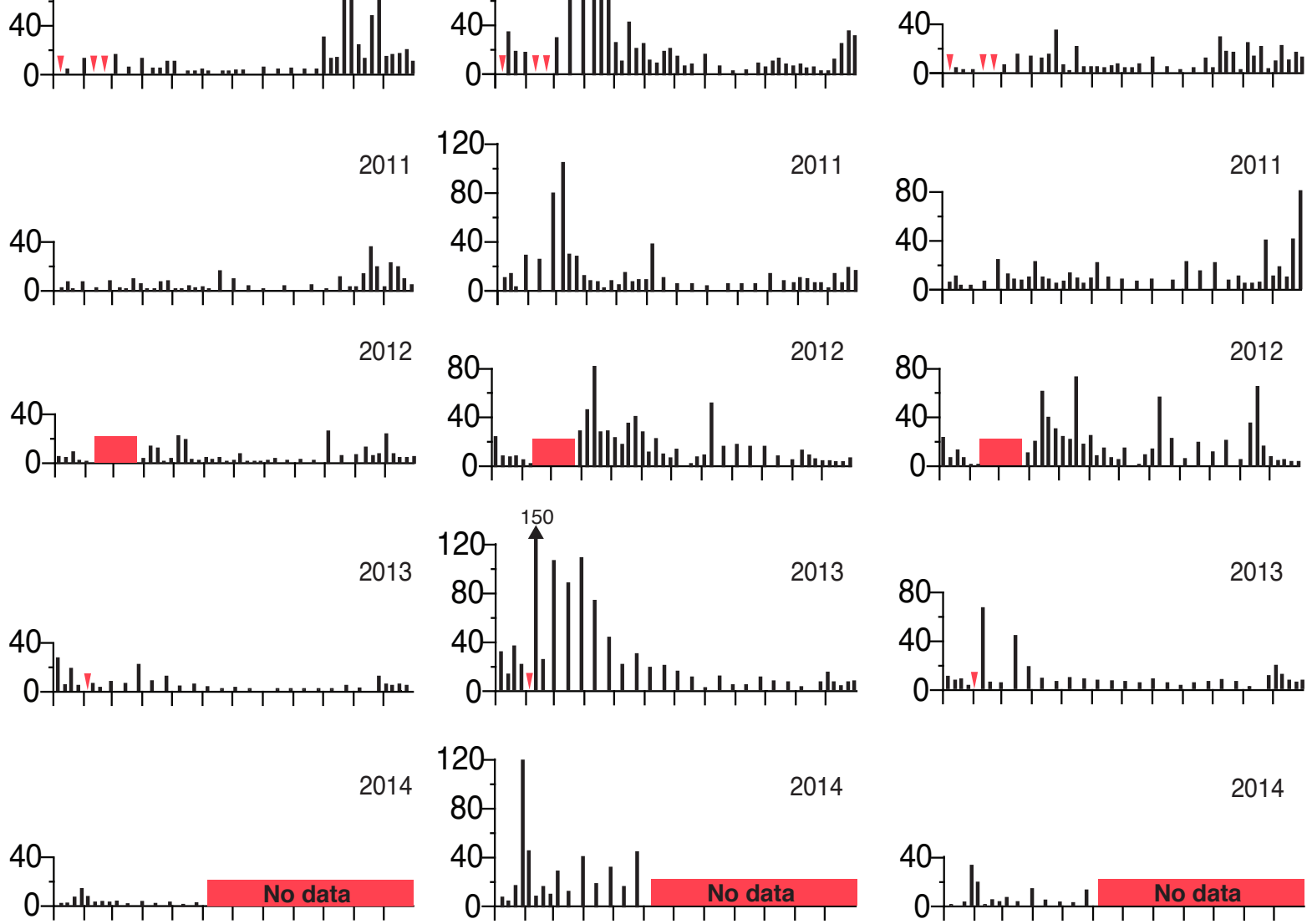

J FMAM J JASOND
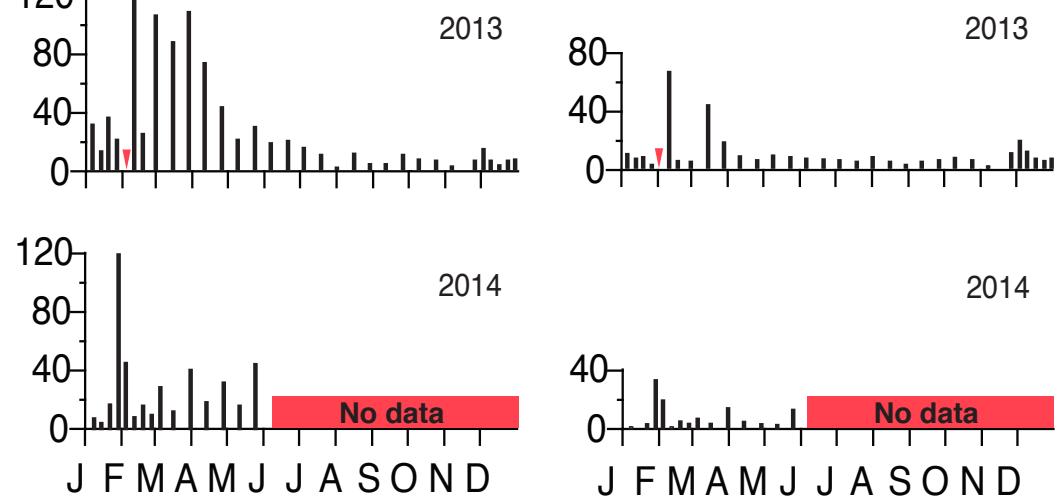

Figure 4. Average daily flux of 7- to 14-day-long sampling intervals of all planktic foraminifers and the 10 most abundant taxa during 2008-14. Note the scale change on the $y$-axis. Tick marks on the $x$-axis denote the first day of each month. Red bars indicate a gap in sampling from late May to late September 2009, from early February to late March 2012, and from June to December 2014. Red inverted triangles indicate the loss of ten sampling cups in 2009, 2010, and 2013. Abbreviation: $\mathrm{m}^{-2}$ day $^{-1}$, per square meter per day.-Continued 


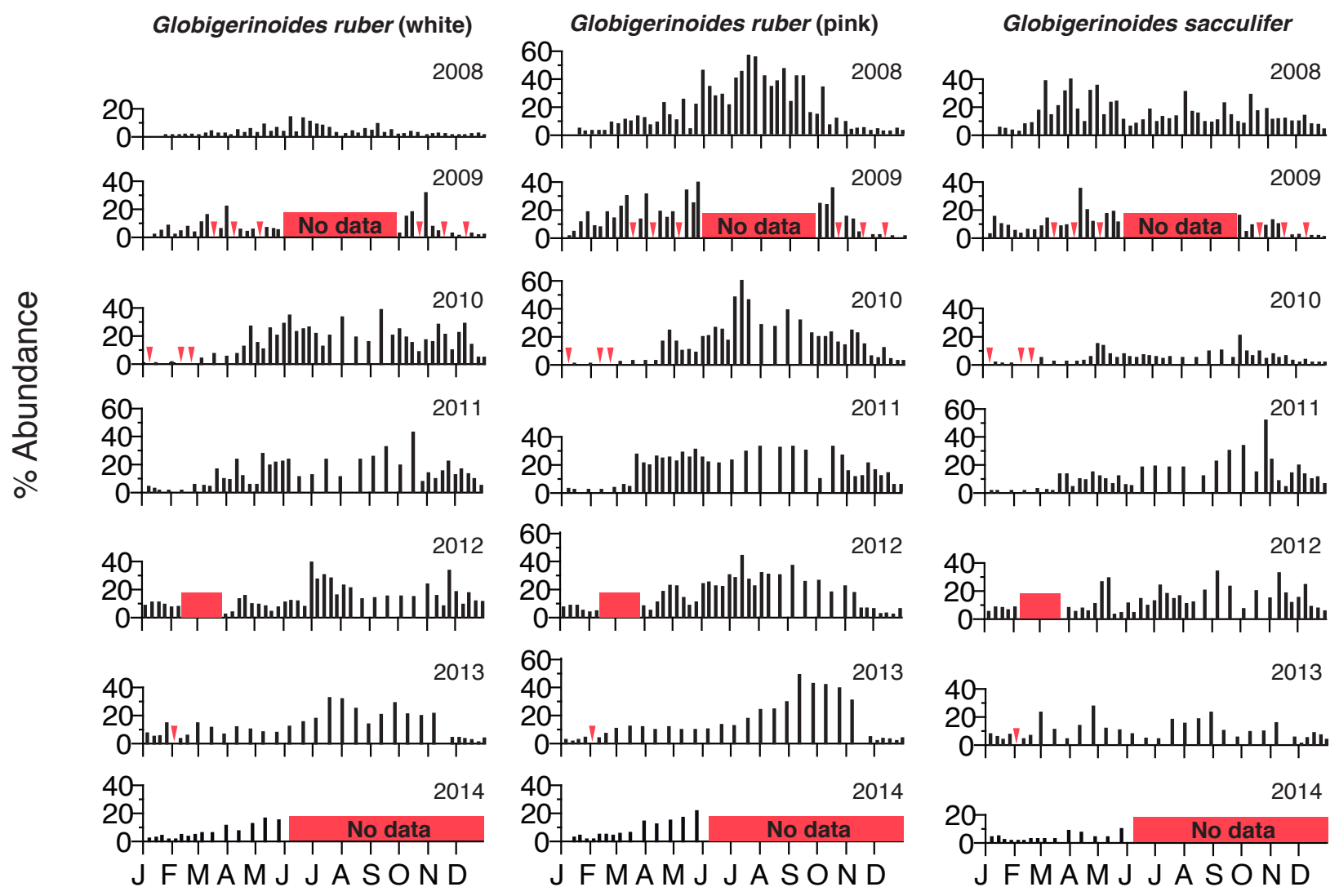

Figure 5. Weekly relative abundance, in percent $(\%)$, of the 10 most common taxa of planktic foraminifers during 2008-14. Note the scale change on the $y$-axis. Tick marks on the $x$-axis denote the first day of each month. Red bars indicate a gap in sampling from late May to late September 2009, from early February to late March 2012, and from June to December 2014. Red inverted triangles indicate the loss of ten sampling cups in 2009, 2010, and 2013. 
Globorotalia menardii group

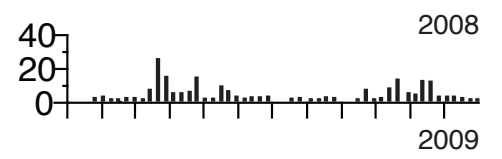

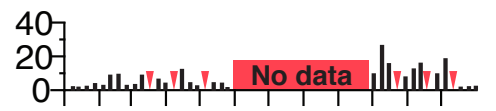
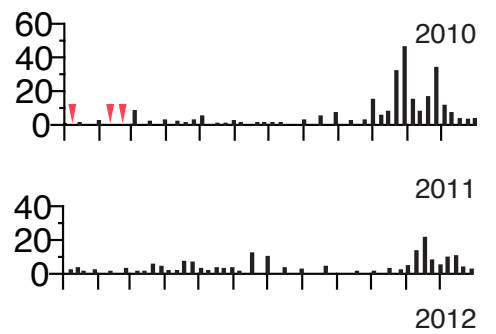

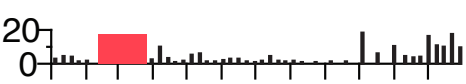

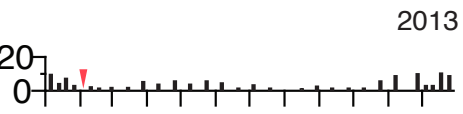

0
0
$\frac{0}{0}$
$\frac{0}{0}$
$\frac{1}{3}$
$\frac{0}{4}$
0

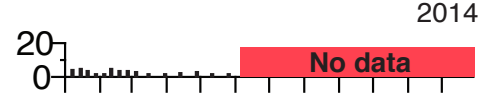

J FMAMJ J A SOND
Globigerina calida

$40-2008$

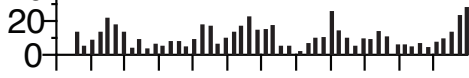

6072009

$40-$

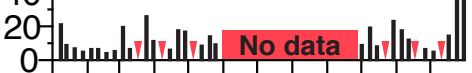

60- 2010

الس.س, 2010

60- 2011

2011

2012

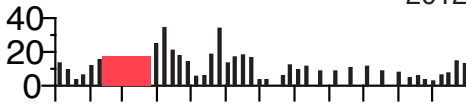

الس 2013

2014

J FMAM J JASOND
Globigerinella aequilateralis

2008

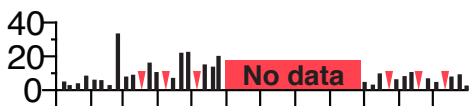

2010

سلإسل, 20, 20

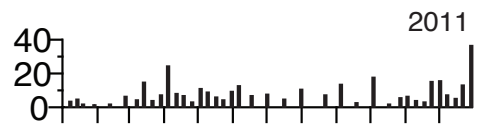

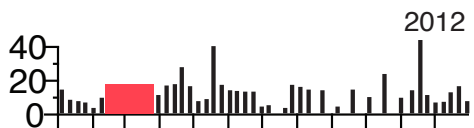

407

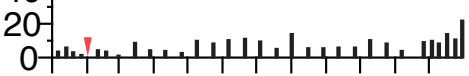

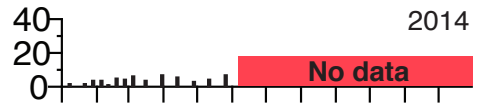

J FMAMJ JASOND
Orbulina universa
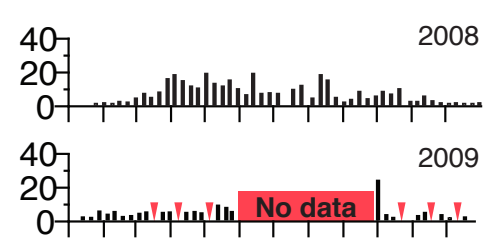

2010
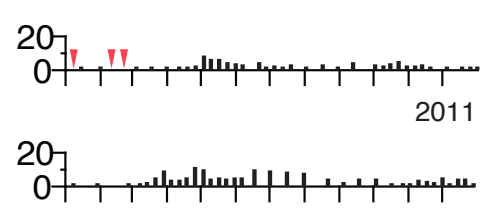

2012

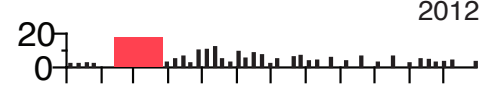

2013
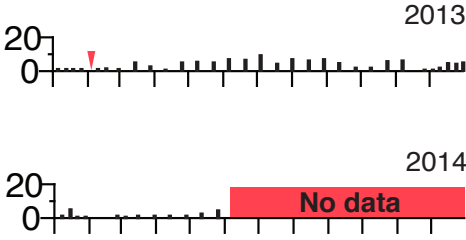

$J F M A M J J A S O N D$

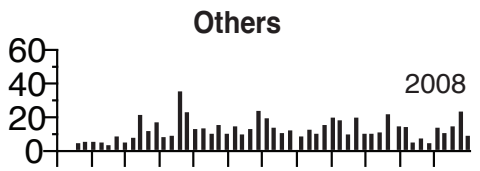

40. 2009

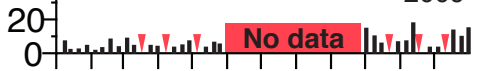

2010

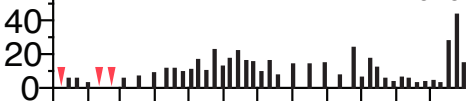

2011

|لس

2012

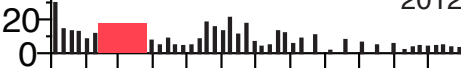

2013

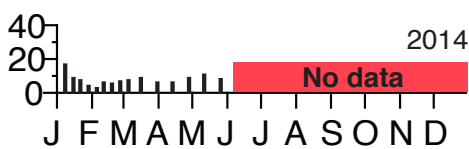

Figure 5. Weekly relative abundance, in percent (\%), of the 10 most common taxa of planktic foraminifers during 2008-14. Note the scale change on the $y$-axis. Tick marks on the $x$-axis denote the first day of each month. Red bars indicate a gap in sampling from late May to late September 2009, from early February to late March 2012, and from June to December 2014. Red inverted triangles indicate the loss of ten sampling cups in 2009, 2010, and 2013.-Continued 


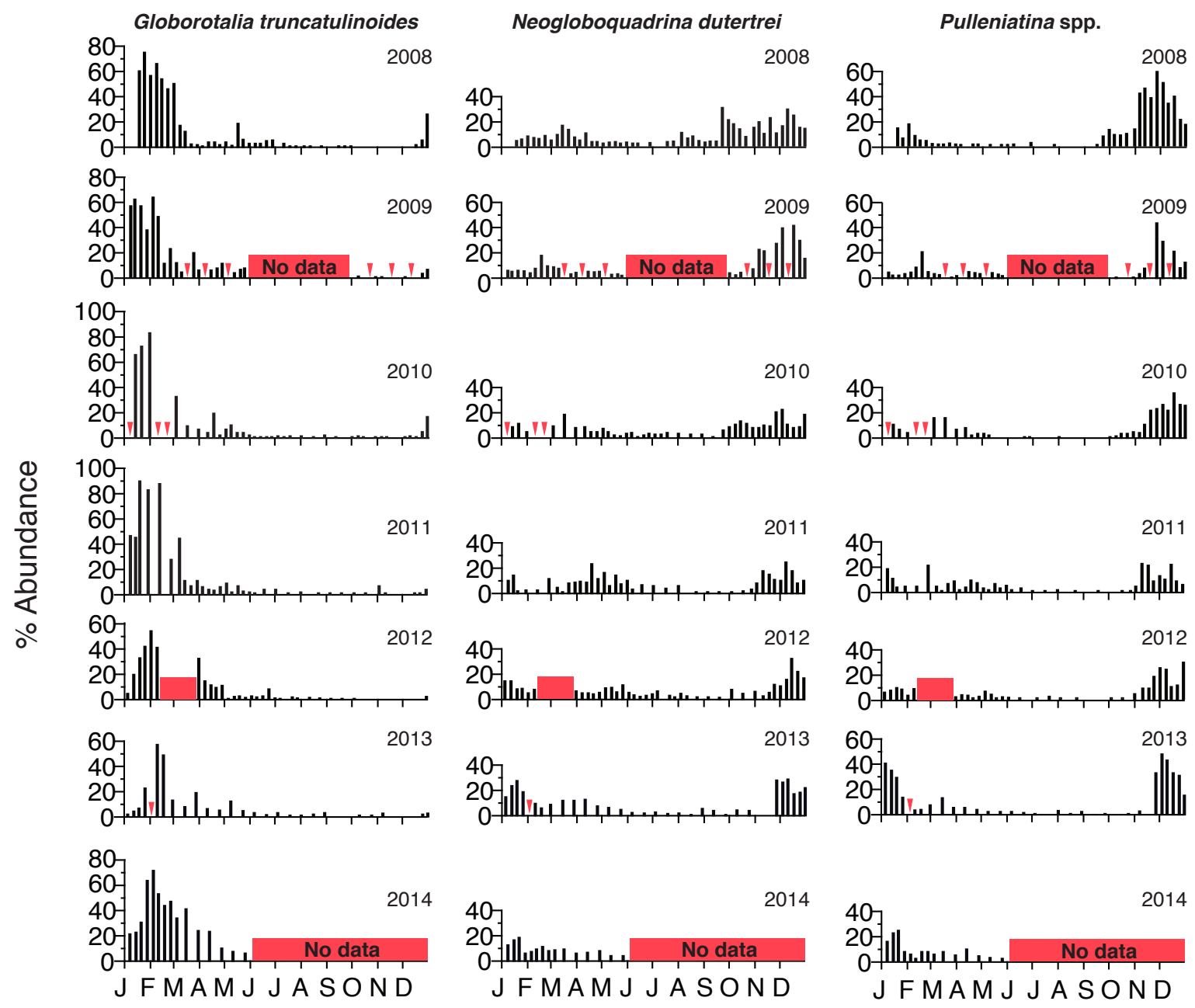

Figure 5. Weekly relative abundance, in percent (\%), of the 10 most common taxa of planktic foraminifers during 2008-14. Note the scale change on the $y$-axis. Tick marks on the $x$-axis denote the first day of each month. Red bars indicate a gap in sampling from late May to late September 2009, from early February to late March 2012, and from June to December 2014. Red inverted triangles indicate the loss of ten sampling cups in 2009, 2010, and 2013.-Continued 